\title{
ASSESSMENT OF THE CONSTRUCTION AND CHARACTERISTICS OF COATINGS FOR USE IN POWER BOILERS
}

\author{
${ }^{1}$ Aleksandra KUCHARCZYK, ${ }^{1}$ Lidia ADAMCZYK, ${ }^{1}$ Agata DUDEK, ${ }^{2}$ Rafał KOBYŁECKI \\ ${ }^{1}$ Czestochowa University of Technology, Faculty of Production Engineering and Materials Technology, \\ Poland,EU, aleksandra.kucharczyk@pcz.pl, lidia.adamczyk@pcz.pl, agata.dudek@pcz.pl \\ ${ }^{2}$ Czestochowa University of Technology, Faculty of Infrastructure and Environment, Poland, EU, \\ rafal.kobylecki@pcz.pl
}

https://doi.org/10.37904/metal.2021.4198

\begin{abstract}
The article presents the results of tests of the coating material intended for the elements of boilers in the power industry (water walls, steam superheaters). The coatings were applied by thermal spraying, which is one of the basic technologies in surface engineering. The use of this method enables the production of coatings with a specific chemical and phase composition, and structure. The coatings were applied to parts of energy equipment made of alloy, heat-resistant steel (16Mo3). The structure and properties of the protective coatings were analyzed using a light microscope, SEM, X-ray diffractometer and a micro hardness tester.
\end{abstract}

Keywords: Thermal spraying, power industry, anti-corrosion coating

\section{INTRODUCTION}

The most common cause of the weakening of the material that builds the elements of working installations in the power industry, erosive and corrosive wear processes are combined. In addition, high temperature, accompanying these processes during the operation of machines and devices, intensifies their occurrence and creates major problems in the operation of energy devices. The problem of erosive and corrosive wear is most visible in the combustion chamber, on the surfaces of superheaters, economizers and in the fuel and air supply systems to the boiler and the ash removal system [1,2]. By influencing the speed and shape of the flue gas stream, erosive wear and corrosive can be effectively reduced. It is possible due to the use of better materials for the construction of the boiler chamber and installation components. The use of this type of optimization of structure elements influences, among others to reduce wear of essential boiler components. The use of humps in exhaust gas ducts or choke plates at heaters is a good example of this type of modification [1].

The second method of protecting the most exposed to wear elements is the use of special overlays or protective coatings made of highly wear-resistant materials. Protective coatings used in the energy industry must be characterized by high durability due to the long-term operation of these devices in an unfavorable environment. Coatings produced by welding or thermal spraying bring the greatest protective effects [3]. The thermal spraying method can produce protective coatings from practically all known coating materials, on any substrate [4]. Materials used for protective coatings should meet the following conditions: stability under conditions not exceeding the melting point of $3000^{\circ} \mathrm{C}$. Thus, these materials cannot undergo chemical processes, such as evaporation or dissociation, until this temperature is reached [5]. The main task of thermally sprayed coatings is to protect the base material against corrosion, external and internal stimuli, and to ensure high abrasion resistance [6,7], even on stainless steel $[8,9]$. Well-produced coatings create a thermal barrier on the protected surface, which protects the material against high temperatures. In addition, the coating can give the protected surface special electrical, magnetic or other properties, which also increase its temperature resistance, hardness and thickness [10]. The deposited coating can be further improved by laser treatment 
[11,12], thus making it possible to improve the technological properties [13,14]. Surfaces improved by applying an additional coating are of interest not only to the power industry [15,16], but also to the automotive industry $[17,18]$, manufacturers of agricultural equipment $[19,20]$ and producers of bioimplants operating in a corrosively aggressive environment [21].

The thermal spraying method uses coating materials that are characteristic of a given spraying method [22]. It is used, inter alia, powders, rods and solid or flux cored wires. For the arc and flame wire methods, solid or flux cored wires are used, the diameter of which depends on the type of device and ranges from 1.6 to $5 \mathrm{~mm}$. An important requirement in selecting a coating material in the arc method is the conductivity of electric current through the wire. Other methods, such as flame powder and supersonic, use metallic powders, metal-ceramic and ceramic composite powders as well as thermoplastic plastics as the coating material $[4,5]$. Table 1 presents selected examples of materials used in the production of coatings by thermal spraying.

Table 1 Materials used for thermal spraying of coatings [4]

\begin{tabular}{|c|c|c|}
\hline Type of material weakening & Spraying methods & Material group \\
\hline \multirow[b]{2}{*}{ Atmospheric corrosion } & Flame & $\begin{array}{l}\text { Wires of } \mathrm{Zn}, \mathrm{Zn}-\mathrm{Al} \text { alloys., } \mathrm{Al}, \mathrm{Al}-\mathrm{Mg} \\
\text { Powders: } \mathrm{Al}_{2} \mathrm{O}_{3}, \mathrm{Al}_{2} \mathrm{O}_{3}-\mathrm{TiO}_{2}, \mathrm{CrO}_{2}\end{array}$ \\
\hline & Arc & $\begin{array}{l}\text { Wires of } \mathrm{Zn}, \mathrm{Zn}-\mathrm{Al} \text { alloys., } \mathrm{Al}, \mathrm{Al}-\mathrm{Mg} \\
\text { Powders: } \mathrm{Al}_{2} \mathrm{O}_{3}, \mathrm{Al}_{2} \mathrm{O}_{3}-\mathrm{TiO}_{2}, \mathrm{CrO}_{2} \\
\text { Stainless steel, alloys based on } \mathrm{NiCr}\end{array}$ \\
\hline \multirow{3}{*}{ High temperature corrosion } & Flame & $\begin{array}{c}\text { Wires } \mathrm{Al} \text {, alloys with high content of } \mathrm{Cr} \text { on } \mathrm{Ni} \text { or } \\
\qquad \mathrm{Fe} \text { matrix } \\
\text { Powders: } \mathrm{ZrO}_{2}, \mathrm{ZrO}_{2}+\mathrm{Y}_{2} \mathrm{O}_{3}, \mathrm{Al}_{2} \mathrm{O}_{3}\end{array}$ \\
\hline & Plasma & $\mathrm{ZrO}_{2}, \mathrm{ZrO}_{2}+$ modifications $\mathrm{Y}_{2} \mathrm{O}_{3}$ and others \\
\hline & Arc & $\begin{array}{c}\mathrm{Al} \text {, alloys with a high content of } \mathrm{Cr} \text { on a } \mathrm{Ni} \text { or } \mathrm{Fe} \\
\text { matrix }\end{array}$ \\
\hline \multirow{3}{*}{ Abrasive wear } & Flame & Self- fluxing powders with remelting \\
\hline & Arc & $\begin{array}{l}\text { Wires based on Fe Or Ni modified with the } \\
\text { phases of carbides, borides, silicides, etc. }\end{array}$ \\
\hline & HVOF & $\begin{array}{c}\text { Composite powders type: WC-Co, WC-Co-Cr, } \\
\text { NiCr- } \mathrm{Cr}_{3} \mathrm{C}_{2} \text {, WC-CrC-Ni }\end{array}$ \\
\hline \multirow{2}{*}{$\begin{array}{l}\text { Abrasive and corrosive wear AT } \\
\text { elevated temperatures }\end{array}$} & Arc & $\begin{array}{l}\mathrm{Ni} \text { - based wires modified with the phases of } \\
\text { carbides, borides, silicides, etc. }\end{array}$ \\
\hline & HVOF & $\begin{array}{c}\mathrm{NiCr}-\mathrm{Cr}_{3} \mathrm{C}_{2}, \mathrm{NiCr}-\mathrm{Cr}_{3} \mathrm{C}_{2} \text { powders with additional } \\
\text { modifications, e.g. } \mathrm{Cr}_{3} \mathrm{C}_{2}-\mathrm{TiC}-\mathrm{NiCr} \text {, WC- } \mathrm{Cr}_{3} \mathrm{C}_{2}- \\
\mathrm{NiCr} \text { or } \mathrm{Ni}\end{array}$ \\
\hline
\end{tabular}

\section{EXPERIMENTAL PART}

The test samples were taken from the parts used in the production of accessories for heating boilers. These parts were made of $16 \mathrm{Mo} 3$ steel. In order to increase the resistance to the corrosive environment, the metal surface was covered with a protective coating using the thermal arc spraying method. The chemical composition of the $16 \mathrm{Mo} 3$ heat-resistant alloy steel is presented in Table 2.

Table 2 Chemical composition of $16 \mathrm{Mo} 3$ steel (wt\%)

\begin{tabular}{|c|c|c|c|c|c|c|c|c|c|c|}
\hline $\mathbf{C}$ & $\mathbf{M n}$ & $\mathbf{S i}$ & $\mathbf{P}$ & $\mathbf{S}$ & $\mathbf{C r}$ & $\mathbf{M o}$ & $\mathbf{N i}$ & $\mathbf{C u}$ & $\mathbf{A l}$ & $\mathbf{N}$ \\
\hline $0,12-0,20$ & $0,4-0,9$ & $<0,35$ & $<0,025$ & $<0,010$ & $<0,3$ & $0,25-0,35$ & $<0,3$ & $<0,3$ & - & $<0,012$ \\
\hline
\end{tabular}

The microstructure studies were performed using the OLYMPUS GX41 light microscope and the JEOL scanning electron microscope (SEM). The selected test results are shown in (Figure 1) and (Figure 2). The 
analysis carried out on a scanning microscope and on an optical microscope of the coating showed that it is characterized by a lamellar structure. The coating consists of many particles (lamellas) formed by successive sprayed particles. As results from the analysis of the coating-substrate connection zone, the coating shows very good adhesion to the substrate. It was confirmed that $16 \mathrm{Mo} 3$ steel has a ferritic-pearlitic structure. The average thickness of the coating was $329.45 \mu \mathrm{m}$.
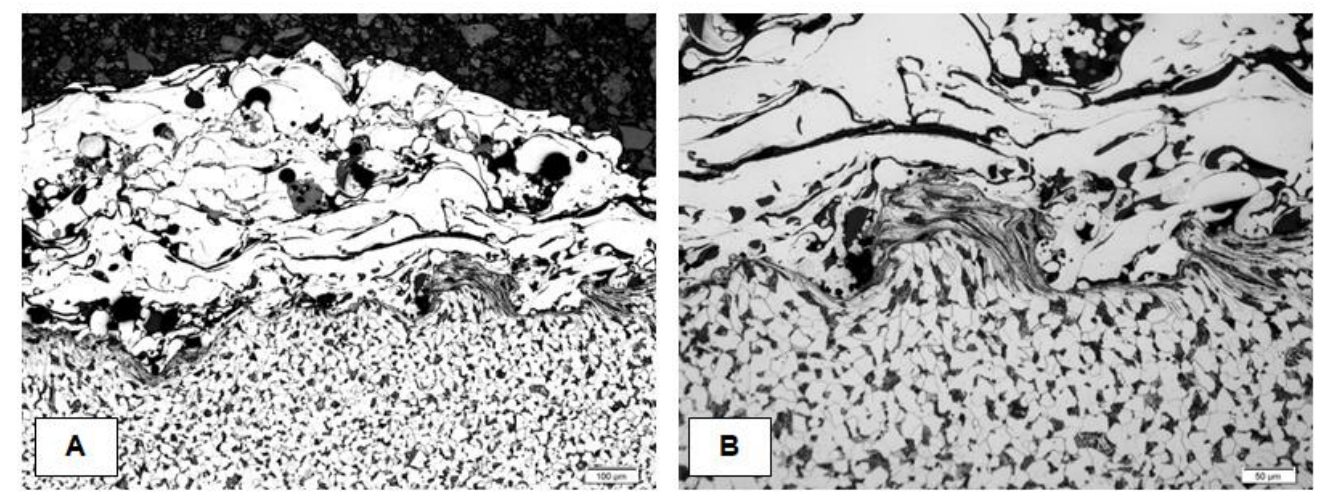

Figure 1 Cross- section of the tested sample- $16 \mathrm{Mo3}$ steel with coating, Olympus GX41
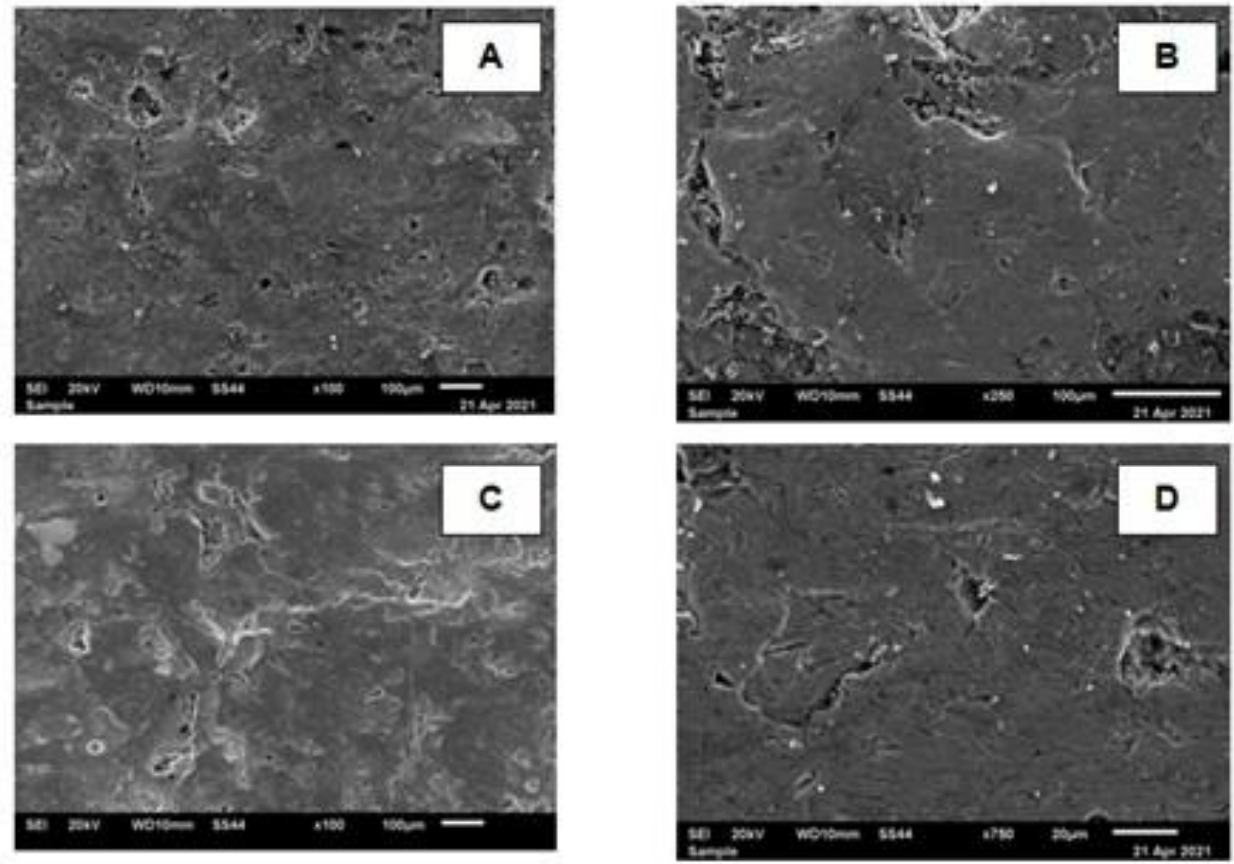

Figure 2 Structure and morphology of the surface of the sprayed coatings (SEM)

The coatings applied to the steel substrate were subsequently analyzed for their chemical composition on a scanning microscope equipped with an X-ray chemical composition analyzer (EDX). The results are shown in Table 3 and (Figure 3).

Table 3 Chemical composition of the coating on $16 \mathrm{Mo} 3$ steel

\begin{tabular}{|c|c|c|c|c|c|c|c|c|c|c|c|c|}
\hline Element & C-K & O-K & Mg-K & Al-K & Si-K & Ca-K & Cr-K & Mn-K & Fe-K & Mo-K & W-K & Total \\
\hline Weight\% & 6,43 & 5,14 & 0,34 & 0,21 & 1,19 & 0,36 & 19,69 & 0,73 & 62,60 & 1,44 & 1,86 & \\
\cline { 1 - 2 } Atomic\% & 21,7 & 13,02 & 0,57 & 0,32 & 1,72 & 0,37 & 15,34 & 0,54 & 45,51 & 0,61 & 0,41 & 100 \\
\hline
\end{tabular}




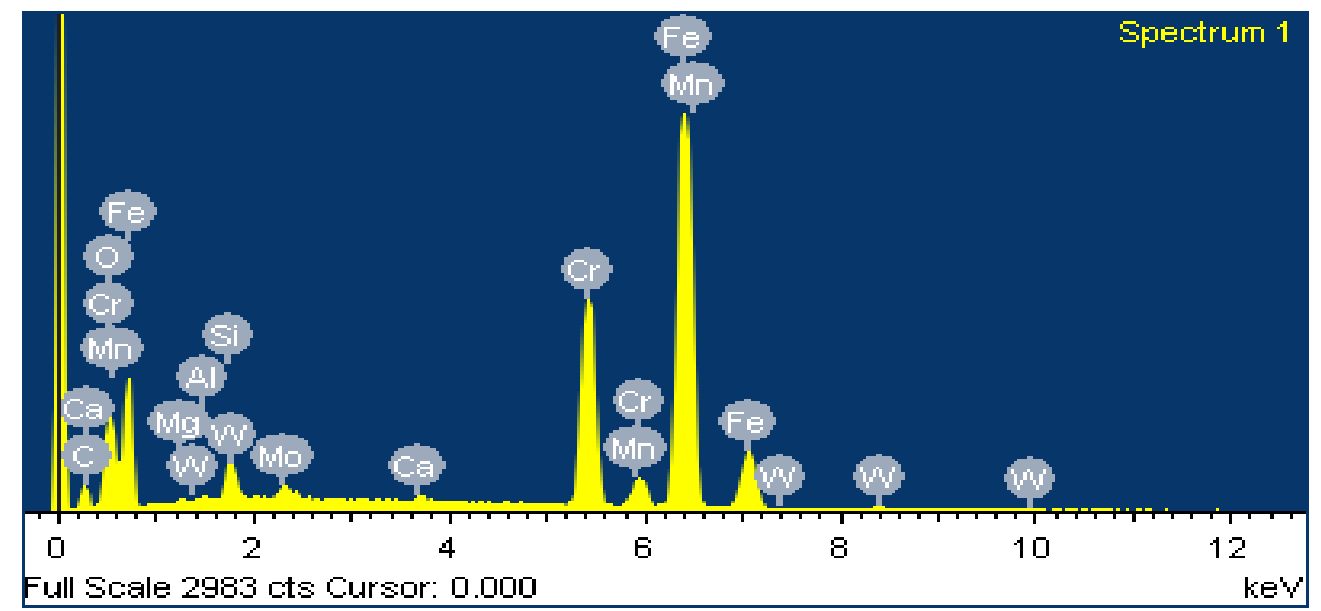

Figure 3 Chemical composition SEM/EDX

Figure 4 shows the diffractogram for a sample of steel with an applied coating. The $X-$ ray diffractometer Seifert $3003 \mathrm{~T}-\mathrm{T}$ with a cobalt lamp $\lambda$ cok $\alpha=0.17902 \mathrm{~nm}$ was used for identification of phase composition of coating. XRD patterns from angle $40-130^{\circ} 2 \theta$ were recorded with the following measurement conditions: tube voltage of $40 \mathrm{kV}$, tube current of $30 \mathrm{~mA}$, step-scan mode with a step size of $0.2^{\circ}$ and counting time of $10 \mathrm{~s}$ per step. After the analysis, the presence of the Fe phase was confirmed (peaks 1-4). However, it should be remembered that identical peak positions are characteristic for chromium. This element is also found in the composition of the coating ( $\mathrm{Fe} / \mathrm{Cr})$.

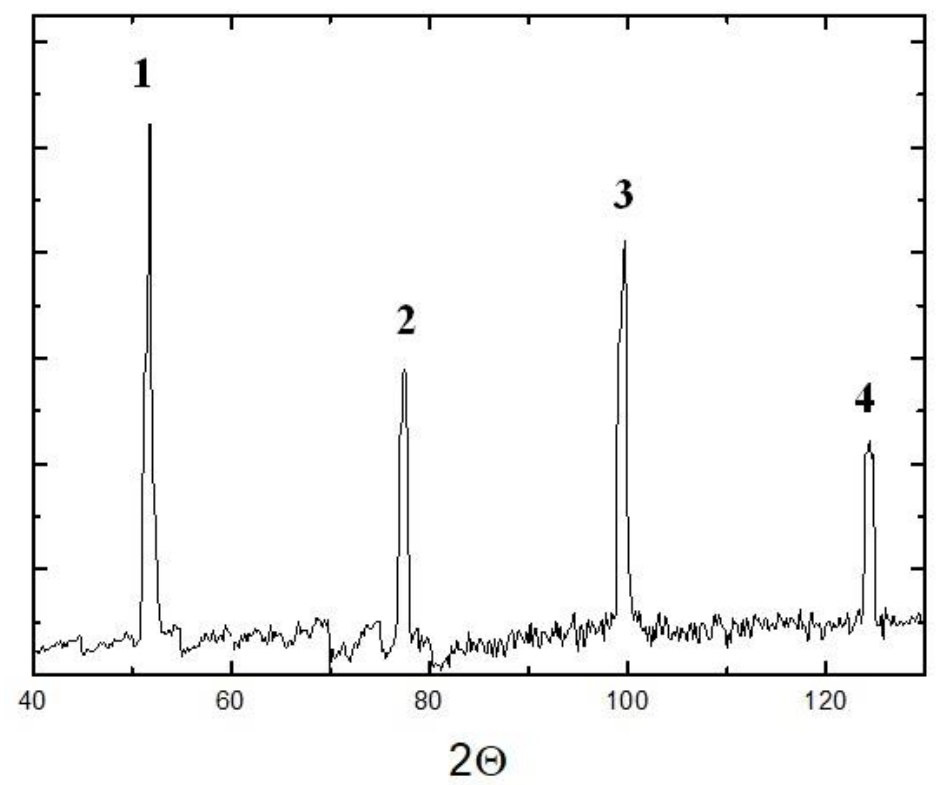

Figure 4 Diffractogram for $16 \mathrm{Mo} 3$ steel coated with the thermal spray method

In the next stage, the hardness of the substrate and the coating were tested using a Shimadzu HMV-G Series microhardness tester. The Vickers microhardness test (HV 0.1) was performed for a load of $0.980 \mathrm{~N}$. Several hardness measurements were carried out for both the steel substrate and the protective coating. Based on the obtained results, the average value was calculated, which for the substrate (16Mo3 steel) was $163 \mathrm{HV}$, while in the case of the coating it was $797 \mathrm{HV}$. Additionally, standard deviations for the substrate and the protective coating were calculated. The data is summarized in the column chart (Figure 5). 


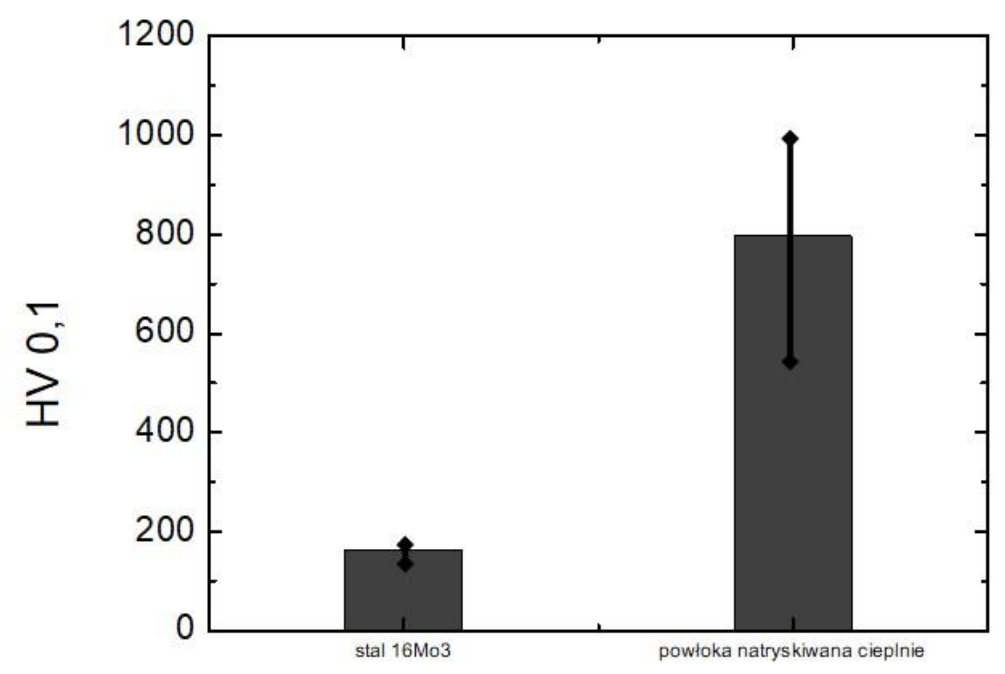

Figure 5 Average hardness value for the substrate (16Mo3 steel) and the coating

\section{CONCLUSION}

Coatings produced by thermal arc spraying from a selected coating material $(\mathrm{Fe} / \mathrm{Cr}$ ) adhere well to the substrate, which is advantageous from the point of view of performance. They are about $300 \mu \mathrm{m}$ thick, which is important for their resistance to corrosive and erosive wear. The proposal of applying the coatings by this method allows to reduce the production costs due to the simple equipment and inexpensive coating material. The presented article presents selected test results of coatings intended for anti-corrosion and anti-erosion protection of selected accessories of heating boilers. Thermal arc spray coatings are an example of structurally advanced materials that can be used, for example in the energy industry.

\section{REFERENCES}

[1] FORMANEK, B., SZYMAŃSKI, K., HERNAS, A. Natryskiwanie cieplnie powłoki odporne na zużycie erozyjne i korozyjne dla kotłów energetycznych. Inżynieria Materiałowa. 2011, vol. 32, iss. 4, pp. 399-402.

[2] FORMANEK, B., SZYMAŃSKI, K., HERNAS, A. Trwałość eksploatacyjna natryskiwanych cieplnie powłok do ochrony ścian kotłów fluidalnych CFB. Problemy Eksploatacji. 2012, vol. 2, pp. 57-66.

[3] FORMANEK, B., SZYMAŃSKI, K., CHMIELA, B., SCZUCKA- LASOTA, B. Wielofazowe kompozytowe powłoki dla zwiększenia odporności korozyjnej natryskiwanych cieplnie powłok. Ochrona Przed Korozją. 2009, vol. 52, pp. 270-275.

[4] FORMANEK, B., SZYMAŃSKI, K., KUCZOWITZ, B. Odporne na korozję i zużycie ścierne powłoki otrzymywane metodami natryskiwania cieplnego. Ochrona Przed Korozją. 2010, vol. 53, pp. 164-168.

[5] LIPIŃSKI, T., WACH, A. Dimensional structure of non-metallic inclusions in high-grade medium carbon steel melted in an electric furnace and subjected to desulfurization. Solid State Phenom. 2015. vol.223, pp. 46-53.

[6] JAGIELSKA-WIADEREK, K., BALA, H., WIECZOREK, P., RUDNICKI, J., KLIMECKA-TATAR, D. Corrosion resistance depth profiles of nitrided layers on austenitic stainless steel produced at elevated temperatures. Arch. Metall. Mater. 2009, vol. 54, pp. 115-120.

[7] SKRZYPCZAK-PIETRASZEK, E., URBANSKA, A., ZMUDZKI, P., PIETRASZEK, J. Elicitation with methyl jasmonate combined with cultivation in the Plantform ${ }^{\mathrm{TM}}$ temporary immersion bioreactor highly increases the accumulation of selected centellosides and phenolics in Centella asiatica (L.) Urban shoot culture. Engineering in Life Sciences. 2019. vol. 19, pp.931-943.

[8] SZABRACKI, P., LIPIŃSKI, T. Effect of aging on the microstructure and the intergranular corrosion resistance of X2CrNiMoN25-7-4 duplex stainless steel. Solid State Phenom. 2013, vol. 203-204, pp. 59-62. 
[9] SZABRACKI, P., LIPINSKI, T. Influence of sigma phase precipitation on the intergranular corrosion resistance of X2CrNiMoN25-7-4 super duplex stainless steel. In: METAL 2014: 23 ${ }^{\text {rd }}$ Int. Conf. on Metallurgy and Materials. Ostrava: TANGER, 2014, pp. 476-481.

[10] RADEK, N., SLADEK, A., BRONCEK, J., BILSKA, I., SZCZOTOK, A. Electrospark alloying of carbon steel with WC-Co-Al2O3: Deposition technique and coating properties. Adv. Mat. Res.-Switz. 2014, vol. 874, pp. 101-106.

[11] RADEK, N., WAJS, E., LUCHKA, M. The WC-Co electrospark alloying coatings modified by laser treatment. Powder Metall. Met. Ceram. 2008, vol. 47, pp. 197-201.

[12] RADEK, N., KONSTANTY, J. Cermet ESD coatings modified by laser treatment. Arch. Metall. Mater. 2012 , vol. 57, pp. 665-670.

[13] DWORNICKA, R., RADEK, N., KRAWCZYK, M., OSOCHA, P., POBȨDZA, J. The laser textured surfaces of the silicon carbide analyzed with the bootstrapped tribology model. In: METAL 2017: 26 th Int. Conf. Metall. and Mater. Ostrava: TANGER, 2017, pp. 1252-1257.

[14] RADEK, N., SZCZOTOK, A., GĄDEK-MOSZCZAK, A., DWORNICKA, R., BRONČEK, J., PIETRASZEK, J. The impact of laser processing parameters on the properties of electro-spark deposited coatings. Arch. Metall. Mater. 2018, vol. 63, pp. 809-816.

[15] ORMAN, Ł.J. Boiling heat transfer on meshed surfaces of different aperture. AIP Conf. Proc. 2014, vol. 1608, pp. 169-172.

[16] RADEK, N., ORMAN, Ł.J., PIETRASZEK, J., BRONČEK, J. Verification of correlations for pool boiling heat transfer on horizontal meshed heaters. Materials Research Proceedings. 2020, vol. 17, pp. 185-190.

[17] CZERWIŃSKA, K., DWORNICKA, R., PACANA, A. Improvement of the surface of the combustion chamber of a piston using selected techniques of production organization. Materials Research Proceedings. 2020, vol. 17, pp. 270-275.

[18] LIPINSKI, T. Influence of surface refinement on microstructure of Al-Si cast alloys processed by welding method. Manuf. Technol. 2015, vol. 15, pp. 576-581.

[19] LIPINSKI, T., KARPISZ, D. Corrosion rate of 1.4152 stainless steel in a hot nitrate acid. In: METAL 2019: $28^{\text {th }}$ Int. Conf. Metallurgy and Materials. Ostrava: TANGER, 2019, pp. 1086-1091.

[20] LIPINSKI, T., KARPISZ, D. Effect of animal slurry on carbon structural S235JR steel at $318 \mathrm{~K}$. In: METAL 2020: $29^{\text {th }}$ Int. Conf. Metall. and Mater. Ostrava: TANGER, 2020, pp. 643-648.

[21] KLIMECKA-TATAR, D. Electrochemical characteristics of titanium for dental implants in case of the electroless surface modification. Arch. Metall. Mater. 2016. vol. 61, pp. 923-26.

[22] SZALA, M., DUDEK, A., MARUSZCZYK, A., WALCZAK, M., CHMIEL, J., KOWAL, M. Effect of atmospheric plasma sprayed TiO2-10\% NiAl cermet coating thickness on cavitation erosion, sliding and abrasive wear resistance. Acta Phys. Pol. A. 2019, vol. 136, pp. 335-341. 